

\section{ETIKA GURU \\ PENDIDIKAN AGAMA KRISTEN}

Dr. Sandy Ariawan, S.M.G., S.Pd.K., M.A., M.Pd.K.

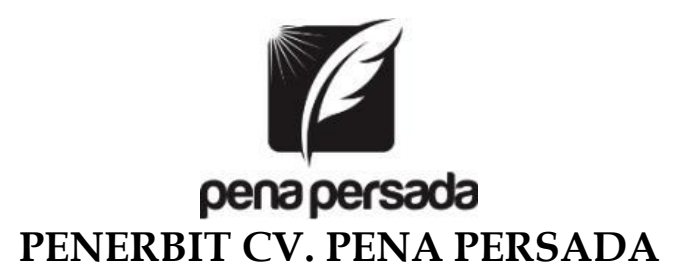




\section{ETIKA GURU \\ PENDIDIKAN AGAMA KRISTEN}

\section{Penulis :}

Dr. Sandy Ariawan, S.M.G., S.Pd.K., M.A., M.Pd.K.

ISBN : 978-623-6504-69-7

Design Cover :

Retnani Nur Briliant

Layout :

Nisa Falahia

\section{Penerbit CV. Pena Persada}

Redaksi :

Jl. Gerilya No. 292 Purwokerto Selatan, Kab. Banyumas

Jawa Tengah

Email : penerbit.penapersada@gmail.com

Website : penapersada.com

Phone : (0281) 7771388

\section{Anggota IKAPI}

All right reserved

Cetakan pertama : 2020

Hak cipta dilindungi oleh undang-undang. Dilarang memperbanyak karya tulis ini dalam bentuk apapun tanpa ijin penerbit. 


\section{UCAPAN TERIMAKASIH}

Ungkapan terima kasih dan rasa bangga untuk putraputriku tercinta:

$\checkmark$ Immanuel

- Suah Suarni

$\checkmark$ Priska

- Oktavia

$\checkmark$ Enas

$\checkmark$ Elsy

- Terpina

$\checkmark$ Edi

- Astuti Lestari

- Meidya Dwi Ayuningrum

- Uniek Dini Damayanti

$\checkmark$ Yusmiati Ndode

- Ade Kornelia Putika

- Putriana Muju Riwa

- Nikodemus Purwo Putra

- Chantika Diana Ndjurumbaha

- Aliana Kogoya

- Maria Dian Kristina

- Natanael Ezrajati Kareonesa

- Yarina Kamarigi

- Sediya Kogoy
- El Grace Puspita Abadi

v Kezia Eli Putri

- Samuel Gita Marel

- Celine Vindy Picessa

- Anastasya Diandra Putri

- Cindri

- Sriningsi J. Unjar

- Afleningsih

$\checkmark$ Isramirawati

$\checkmark$ Elisabet

- Rachel

- Yosafat A. Maranatha

- Sely Agustina

- Vita Padmasari

- Christi Apri Wulandari

$\checkmark$ Yesaya

- Hengki

v Windi C. Teti

• Jenika Lusiana Wati

- Rosi Damayanti

- Maya Dorsila Rahayaan 


\section{KATA PENGANTAR}

Di tengah kondisi pandemi Covid-19, yang membuat semua orang di seluruh penjuru dunia merasakan kecemasan, kekhawatiran, kesepian, ketakutan, dan bahkan kepanikan, guru Pendidikan Agama Kristen (PAK) dipanggil secara khusus untuk tetap mengerjakan keselamatan dan mengemban Amanat Agung Yesus. Kendati semua orang berpotensi untuk terjangkit virus corona, namun guru PAK tetap tidak bisa lepas dari tanggung jawab besarnya untuk "menggembalakan" nara didik. Di hati setiap guru PAK telah terpatri panggilan sebagai guru yang datang dan dibarengi dengan panggilan sebagai gembala (pastorteacher).

Buku ini menjadi bahan telaah etika guru Pendidikan Agama Kristen di tengah mengarungi kehidupan yang memasuki era baru yang dinamakan era disrupsi (disruption era). Tantangan yang semakin besar, karena pergeseran aktivitas yang semula dilakukan di dunia nyata berpindah pada dunia maya, menuntut ketajaman setiap guru PAK untuk dapat berpikir seperti Yesus berpikir dan mengambil tindakan seperti Yesus bertindak, seandainya Yesus menghadapi keadaan yang sama. Keputusankeputusan moral etis yang diambil bersumber dari pemahaman yang dalam akan kebenaran Firman Tuhan dan hati yang selalu dipimpin dan diterangi oleh Roh Kudus.

Ungkapan terima kasih yang tulus untuk segenap anakanak rohani angkatan 2018 dan 2019 STIPAK Malang, calon guruguru PAK yang berapi-api melayani Yesus di dunia pendidikan. Ingat dan selalu yakin, bahwa jerih payahmu di dalam Tuhan tidak sia-sia (1 Kor. 15:58).

Malang, 1 Juli 2020

Dr. Sandy Ariawan, S.M.G., S.Pd.K., M.A., M.Pd.K. 


\section{DAFTAR ISI}

UCAPAN TERIMAKASIH........................................................... ii

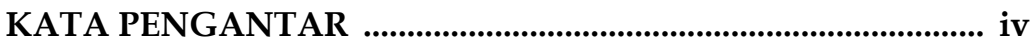

DAFTAR ISI ..................................................................................... v

Bab I Allah Memanggil Saya sebagai Guru PAK ................ 1

Bab II Konsep Etika dan Moral............................................... 6

Bab III Deontologi, Teleologis, dan Kontektual ................ 19

Bab IV Tabiat dan Watak ................................................ 28

Bab V Enam Pandangan Besar Etika ..................................... 42

Bab VI Etika Perjanjian Lama ............................................... 55

Bab VII Etika Perjanjian Lama: Kekudusan dalam

Keluarga ....................................................................... 69

Bab VIII Etika Perjanjian Lama: Kekudusan dalam Seks 82

Bab IX Etika Perjanjian Lama: Kekudusan dalam Harta

Kekayaan....................................................................... 99

Bab X Etika Perjanjian Baru ..................................................... 112

Bab XI Perjanjian Baru Memandang Keteladanan

Hidup Yesus ................................................................. 123

Bab XII Pandangan dan Ajaran Perjanjian Baru Terhadap

Harta Kekayaan ............................................................. 135

BIODATA PENULIS ........................................................................ 145 


\section{ETIKA GURU \\ PENDIDIKAN AGAMA KRISTEN}




\section{BAB I \\ ALLAH MEMANGGIL SAYA SEBAGAI GURU ( PENDIDIKAN AGAMA KRISTEN) PAK}

Salah satu panggilan yang utama dalam diri umat percaya adalah "mengerjakan keselamatan Allah". Dalam pengertian ini, makna "mengerjakan keselamatan Allah" merupakan suatu panggilan iman yang sangat esensial sekaligus universal. Dimaknai sebagai suatu panggilan iman yang esensial, karena makna "mengerjakan keselamatan Allah" pada hakikatnya merupakan manifestasi yang paling nyata dari setiap orang yang mengaku dirinya percaya dan mengasihi Yesus. Sebab bukankah hanya orang-orang yang beriman saja yang mampu menghayati dan mempraktikkan "karya keselamatan" Allah kepada sesamanya? Orang-orang yang tidak percaya kepada Yesus, tidak akan melihat segala tindakan dan perbuatan yang dilakukannya dalam konteks "mengerjakan keselamatan Allah." Mereka hanya akan menganggap segala perbuatan atau tindakannya yang peduli kepada sesama sebagai suatu bentuk dari "humanisme," atau suatu konsekuensi moril sebagai makhluk sosial. Hal ini pun berlaku bagi guru Pendidikan Agama Kristen (PAK), sebagai bagian dari umat percaya yang dipanggil secara khusus oleh Allah.

Inisiatif Allah untuk memanggil setiap guru PAK tentulah berbeda-beda pola dan masanya. Beberapa guru PAK merasakan "getaran" itu melalui suatu rangkaian peristiwa ibadah, sebagaimana yang dialami oleh nabi Yesaya (Yes. 6), meski tak sedikit pula yang dipanggil melalui suatu peristiwa sejarah pergolakan politis seperti halnya yang dialami oleh nabi Yeremia (Yer. 1). Namun tidak jarang, Allah mengetuk hati seseorang dan memanggilnya secara khusus justru pada saat ia sedang bekerja, seperti halnya nabi Musa. Allah memanggil Musa melalui suatu peristiwa alamiah yang mencengangkan yaitu semak duri yang menyala tetapi tidak terbakar (Kel. 3). Penyataan Allah di gunung 
Horeb ini justru terjadi di saat Musa sedang menggembalakan kambing dan domba mertuanya (Kel. 3:1). Maka tampak dengan jelas bahwa Allah memanggil Musa bukan saat dia sedang berdoa, berkontemplasi, berpuasa, atau ketika menghadiri suatu ibadah dan melakukan refleksi teologis di belakang meja, tetapi saat dia sedang bekerja.

Sejatinya, penganiayaan dan perbudakan atas umat Israel di tanah Mesir bukanlah hal yang baru didengar Musa. Kitab Keluaran 1:11 menuliskan "Sebab itu pengawas-pengawas rodi ditempatkan atas mereka untuk menindas mereka dengan kerja paksa: mereka harus mendirikan bagi Firaun kota-kota perbekalan, yakni Pitom dan Raamses," tetapi saat itu Allah belum berkenan menyatakan diri untuk membebaskan umat Israel. Waktu dan rencana Allah tentu sangat berbeda dengan pola perhitungan manusiawi. Barulah dalam Keluaran 3:7 Allah berfirman "Aku telah memperhatikan dengan sungguh kesengsaraan umat-Ku di tanah Mesir, dan Aku telah mendengar seruan mereka yang disebabkan oleh pengerah-pengerah mereka, ya, Aku mengetahui penderitaan mereka." Pada saat itulah Allah menunjukkan bahwa Ia mendengar seruan, penderitaan dan doa-doa mereka, sehingga Ia memutuskan untuk menyatakan karya keselamatan-Nya yang membebaskan umat Israel, sesuai waktu Allah. Ini berarti tugas panggilan yang diemban oleh Musa ditempatkan dalam konteks karya keselamatan Allah yang terjadi di dalam sejarah umat-Nya. Pembebasan umat Israel bukan lagi sekedar suatu upaya humanisme atau perasaan nasionalisme yang mengalir dalam darah dan tubuh Musa. Demikian pula panggilan bagi Musa untuk membebaskan umat Israel dari belenggu perbudakan juga bukan suatu gerakan politis dan penegakan hak asasi manusia. Tetapi panggilan yang diterima oleh Musa benar-benar merupakan manifestasi dari diri Allah yang menyatakan diri dalam panggung sejarah, yaitu menghadirkan karya keselamatanNya dalam kehidupan manusia. 


\section{A. Taat Seperti Yesus}

Di dalam Filipi 2:12, rasul Paulus berkata: "Hai saudarasaudaraku yang kekasih, kamu senantiasa taat; karena itu tetaplah kerjakan keselamatanmu dengan takut dan gentar, bukan saja seperti waktu aku masih hadir, tetapi terlebih pula sekarang waktu aku tidak hadir karena Allahlah yang mengerjakan di dalam kamu baik kemauan maupun pekerjaan menurut kerelaanNya." Konteks ucapan rasul Paulus tersebut muncul dari ulasan kristologisnya tentang Yesus Kristus yang "walaupun dalam rupa Allah, tidak menganggap kesetaraan dengan Allah itu sebagai milik yang harus dipertahankan, melainkan telah mengosongkan diriNya sendiri dan mengambil rupa seorang hamba, dan menjadi sama dengan manusia" (Fil. 2:6-7). Guru Pendidikan Agama Kristen dipanggil untuk mengerjakan keselamatan dengan takut dan gentar didasari oleh suatu spiritualitas dari Tuhan Yesus yang mau mengosongkan dan merendahkan diri-Nya. Dalam hal ini panggilan untuk mengerjakan keselamatan Allah sama sekali bukan didasari oleh perasaan takut akan hukuman Allah dan api neraka; bukan pula didasari untuk memperoleh pahala; juga bukan didasari oleh karena upaya untuk terciptanya suatu keserasian dan keharmonisan hidup bersama. Panggilan dalam diri guru PAK, yang dengan sukacita mau mengerjakan keselamatan Allah dengan takut dan gentar didasari karena karya pengorbanan Kristus yang bersedia mengosongkan diriNya. Kristus yang walaupun sehakikat dengan Allah bersedia menjadi seorang hamba yang taat sampai mati di kayu salib. Filipi 1:8 berkata: "Dan dalam keadaan sebagai manusia, Ia telah merendahkan diri-Nya dan taat sampai mati, bahkan sampai mati di kayu salib. "Dasar yang paling esensial dari pengosongan diri dan pengorbanan Kristus di atas kayu salib adalah karena ketaatan dan sikap kasih-Nya yang mau merendahkan diri. Oleh karena itu, setiap guru PAK mau mengerjakan keselamatan Allah dengan takut dan gentar sejatinya didasari oleh motif untuk mengasihi dan ketaatannya untuk merendahkan diri. 
Kendati demikian dalam kehidupan sehari-hari, tidak jarang dijumpai guru PAK yang mengerjakan keselamatan Allah dengan sikap sombong, sikap puas diri, perasaan diri sebagai orang yang paling benar dan tanpa kasih. Hal tersebut mengakibatkan kegagalan dalam menghadirkan damai sejahtera Allah yang saling memulihkan dalam kehidupan bersama. Padahal apabila mau dikerjakan dengan sungguhsungguh dan mau hidup di dalam Kristus yang mengosongkan diri, maka setiap guru PAK akan dimampukan untuk senantiasa "sehati-sepikir, satu kasih, satu jiwa, satu tujuan dengan tidak mencari kepentingan sendiri atau pujipujian yang sia-sia" (Fil. 2:2-3).

\section{B. Taat Sampai Mati}

Pandemi Covid-19 yang dihadapi dunia memukul semua sektor dan sendi-sendi kehidupan, tidak terkecuali dunia pendidikan. Hal tersebut membuat tantangan untuk terus mengobarkan kasih Ilahi sebagai guru PAK menjadi semakin besar. Tentu pertanyaannya, sebagai guru PAK yang telah ditebus oleh Kristus, akankah tetap mengerjakan keselamatan Allah dengan takut dan gentar justru di saat kita menghadapi situasi kritis dan penderitaan semacam ini? Hal ini akan terjadi manakala setiap guru PAK mengerjakan keselamatan Allah dengan didasari oleh karena sikap kasih yang mau mengosongkan diri seperti sikap Kristus. Semakin seorang guru PAK mampu mengosongkan diri seperti Kristus, maka ia akan dimampukan untuk mengerjakan keselamatan Allah di saat yang kritis dan penuh penderitaan.

Kisah umat Israel saat menghadapi situasi kritis di Rafidim menjadi peringatan bagi setiap umat percaya, tak terkecuali guru PAK, bahwa manusia kerap berubah sikap saat menghadapi persoalan. Di Rafidim, umat Israel tidak mendapat persediaan air (Kel. 17:1). Mereka bersungut-bersungut dan marah kepada Musa. Bukankah hal yang sama juga kerap dialami oleh guru PAK? Sukacita melayani berangsur-angsur menjadi tawar hati, berganti keengganan untuk "mengerjakan 
keselamatan Allah," dan bahkan mulai mempertanyakan makna iman kepada Kristus. Ketaatan justru berubah ke arah negatif menjadi keraguan seperti para pemimpin agama Yahudi yang mempertanyakan kuasa dan otoritas Yesus (Mrk. 11:27-28). Semua hal tersebut menjadikan mata rohani tak lagi dapat melihat karya Allah, yang sejatinya memanggil setiap guru PAK untuk taat sampai mati. 